Fitri Aspatrianti ${ }^{1}$, Dianita Sugiyo

${ }^{1}$ Program Studi IImu Keperawatan, FKIK, UMY, Kasihan, Bantul, Indonesia

E-mail: dianita.sugiyo@gmail.com

\title{
Effect of Self Help Group (SHG) to Stop Smoking Attitudes Among Students
}

\section{Info Artikel:}

Masuk : 28 Agustus 2016

Revisi : 20 November 2016

Diterima : 28 November 2016

DOI Number : 10.18196/ijnp. 1145

\section{ABSTRACT}

The smoking prevalence among youth aged more than 15 years old and so, raising $34,8 \%$ of male and $2,7 \%$ among those female one. Thus, health education program is needed in order to improve youth knowledge on the negative impacts of smoking. This study has been conducted among students of Mexhanical Engineering school in Universitas Muhammadiyah Yogyakarta. This study was a quasy-experimental study. The sample were 52 students who smoked and were divided into two groups, intervention and control gruop. The sampling technique used was random sampling method. Test analysis used Wilcoxon test and Mann-Whitney for attitude. Results : The analysis test showed there was a significant effect of Self Help Group $(\mathrm{SHG})$ on attitude with $\mathrm{p}=0,000(0,05)$. There was a differences on knowledge between intervention and control groups with $p=0,000(p<0,05)$. This new invention on health education method using social media, is important to be developed. Facebook as one of the easy platform of social media to access, will giving more benefit to the community in achieving distance health education.

Key words : smoking behavior, Self Help Group, Facebook, health education, smoking prevalence

\section{ABSTRAK}

Prevalensi perokok remaja usia lebih dari 15 tahun meningkat 34,8\% pada remaja laki-laki dan 2,7\% pada remaja perempuan. Oleh karena itu, pendidikan kesehatan diperlukan untuk meningkatkan pengetahuan remaja terhadap efek negatif bahaya rokok. Penelitian ini dilakukan pada mahasiswa Teknik Mesin UMY., design penelitian dalah quasi eksperimen. Sampel penelitian diambil dengan sistem random, menghasilkan sebanyak 52 sampel mahasiswa perokok yang dibedakan menjadi dua grup, intervensi dan kontrol. 


\section{NURSING PRACTICES}

Analisis data emnggunakan Wilcoxon test dan MannWhitney. Hasil analisis menunjukkan pengaruh yang signifikan SHG terhadap perilaku merokok mahasiswa dengan nilai $\mathrm{p}=0,000$. Terdapat perbedaan tingkat pengetahuan antara kelompok intervensi dan kontrol dengan nilai $p=0,000(p<0,05)$. Penemuan baru dalam metode pendidikan kesehatan ini menggunakan media sosial, sangat penting untuk dikembangkan. Facebook merupakan salah satu bentuk media sosial untuk diakses, akan memberikan banyak manfaat terhadap masyarakat dalam hal pendidikan kesehatan jarak jauh.

Kata kunci: perilaku merokok, Self Help

Group, Facebook, pendidikan kesehatan, prevalensi merokok.

\section{PENDAHULUAN}

Indonesia sekarang ini merupakan surga bagi para perokok dengan pertumbuhan konsumsi rokok yang terbanyak didunia. Survey yang dilakukan oleh Global Adult Tobacco survey (GATS) pada tahun 2011 menunjukkan bahwa Indonesia menduduki posisi teratas di antara 16 negara berkembang lainnya dengan prevalensi perokok aktif tertinggi. Tingginya angka perokok aktif laki-laki di indonesia mencapai 67\% yang akan mempengaruhi kesehatan dan membuat ketidaknyamanan mereka ketika berdekatan dengan orang yang merokok (Aula, 2010).

Rokok membunuh hampir enam juta orang pertahunnya serta lebih dari lima juta perokok yang berasal dari perokok aktif dan lebih dari 600.000 perokok pasif. Sekitar satu orang setiap enam detik akibat dari rokok. Pada tahun 2030, rokok diperkirakan akan menjadi penyebab utama kematian dan kecacatan yang menewaskan 10 juta orang setiap tahun, sekitar 2 juta diantaranya terdapat di Cina. Oleh karena itu, rokok dapat menyebabkan lebih banyak kematian di seluruh dunia, lebih banyak dari gabungan kematian yang disebabkan oleh HIV, TBC dan kematian persalinan. Satu dari dua perokok pada usia muda dan terus merokok seumur hidup dan akhirnya akan meninggal karena penyakit yang berhubungan dengan rokok dan saat ini rokok menjadi suatu permasalahan yang kompleks,
Indonesia sendiri adalah salah satu Negara dengan jumlah penduduk yang terbesar dan menduduki posisi peringkat ketiga dengan jumlah perokok terbesar di dunia (Dinkes, 2012).

Merokok merupakan suatu masalah yang ada di dalam masyarakat yang sampai saat ini sulit untuk diselesaikan. Mengkonsumsi rokok juga dapat menimbulkan banyak kerugian dan dapat menjadi sumber berbagai masalah kesehatan bahkan kematian (Kemenkes RI, 2011). Perilaku merokok merugikan kesehatan karena dapat mengakibatkan banyak penyakit, diantaranya kanker paru (90\%), 75\% penyakit paru obstruktif kronis (PPOK), dan juga menjadi 25\% penyebab dari serangan jantung serta menjadi salah satu penyumbang kematian terbesar di indonesia yang telah mencapai 57.000 orang pertahunnya (RISKESDES,2013).

Pada tahun 2013, terdapat sejumlah 56.860.457 perokok aktif laki-laki dan 1.890 .135 perokok aktif perempuan atau sekitar 58.750 .591 perokok aktif secara keseluruhan dengan usia 10 tahun ke atas. Proporsi perokok aktif terbanyak terlihat pada kelompok usia 2529 tahun yaitu totalnya sebesar 7.785 .730 orang. Pada kelompok laki-laki, proporsi tertinggi pada usia 25-29 tahun sebanyak 7.641.892, sedangkan proporsi untuk terbesar pada kelompok perempuan yaitu usia 45-49 tahun sebanyak 253.273 (TCSIAKMI,2014).

Riset Kesehatan Dasar (RISKESDAS) tahun 2013 masih sama dengan tahun 2010 yaitu satu dari tiga orang satu orang didalamnya adalah perokok. Perilaku merokok sangat bervariasi dari berbagai aspek usia, jenis kelamin, dan kelompok kerja, seperti pada penduduk berusia 10-14 tahun ditemukan 1,4\% perokok dan usia 15 tahun keatas dilaporkan terjadi peningkatan perilaku merokok dari 34,2 \% tahun 2007 menjadi 36,3 tahun 2013. Sementara presentase pengguna rokok 64,9 \% pada laki-laki dan 2,1\% perempuan tahun 2013 (Riskesdas, 2013).

Berdasarkan data Organisasi Kesehatan Dunia (World Health Organization) pada tahun 2011 terdapat 3,8 milyar perokok di dunia. Prevalensi kelompok terbanyak umur 15 tahun ke atas yang merokok setiap harinya pada 5 provinsi di Indonesia tertinggi ditemukan 
di provinsi Kalimantan tengah (36\%), Kepulauan Riau $(33,4 \%)$, Sumatera Barat $(33,1 \%)$, NTT dan Bengkulu masing-masing (33\%). Dan 5 provinsi dengan prevalensi perokok terendah yaitu di provinsi Sulawesi tengah (22 $\%)$, DKI Jakarta (23,9\%), Jawa timur (25,1\%), Bali $(25,1 \%)$, dan Jawa tengah (25,3\%) (RISKESDAS, 2010). Indonesia merupakan negara berkembang dengan tingkat penggunaan rokok yang cukup tinggi. jumlah perokok dari hari ke hari semakin meningkat, usia e"15 tahun sebanyak 34,2\% tahun 2007 (Depkes RI, 2007), kemudian meningkat prevalensinya menjadi $34,7 \%$ di tahun 2010 (Kemenkes RI, 2010) dan meningkat kembali tahun 2011, menurut GATS 2011 jumlah perokok usia 15 tahun sebanyak $34,8 \%$ dengan prevalensi pria $67 \%$ dan perempuan 2,7\% (WHO, 2013).

Adapun faktor yang berpengaruh terhadap tingginya prevalensi merokok di Indonesia yaitu terkait kebiasaan atau budaya di Indonesia. Merokok dianggap sebagai hal yang wajar bagi masyarakat dan bahkan setiap ada acara di mayarakat akan selalu disuguhkan rokok sebagai suguhan utamanya. Apalagi sebagian besar orang Indonesia makan tidak makan yang penting bisa merokok yang dilambangkan dengan kejantanan seseorang (Aula,2010). Kebiasaan - kebiasaan inilah yang akan menghambat untuk mengurangi angka prevalensi merokok di masyarakat, karena secara tidak langsung mereka memberi ruang bagi perokok untuk tetap merokok secara bebas dan menganggap merokok itu sebagai hal yang wajar.

Dari hasil survei yang dilakukan oleh Badan Pusat Statistika (BPS). 2010 menunjukkan bahwa jumlah penduduk di Provinsi Yogyakarta sebanyak 3.457.491 jiwa (BPS,2010). Sementara untuk prevalensi perokok remaja di Provinsi Yogyakarta menurut (BPS,2012), menunjukkan bahwa prevalensi perokok yang paling banyak yaitu remaja dan rata - rata batang rokok yang dihisap oleh remaja di Provinsi DI Yogyakarta sebanyak $31,6 \%$.

Umumnya penyakit yang terkait dengan rokok memerlukan waktu yang lama sekitar 15 - 20 tahun setelah perilaku merokok di mulai, sehingga penyakit yang terkait dengan rokok dan jumlah kematian dimasa mendatang terus meningkat (TCSIAKMI,2014).
Berbagai peraturan ataupun kebijakan serta program yang sudah dijalankan oleh pemerintah Di Yogyakarta, usaha ini tidak akan berjalan apabila kurangnya keinginan untuk benar-benar berhenti merokok. Upaya berhenti merokok secara eksklusif akan menargetkan para perokok yang memiliki keinginan untuk berhenti, terutama untuk individu yang tidak memiliki rencana untuk berhenti merokok dalam waktu dekat (Donovan \& marlatt,2007; Celik,2013;Zakaria,2015).

Menurut data diatas terjadinya peningkatan usia mulai merokok di kalangan remaja sangat mengkhawatirkan karena sangat berisiko bagi kesehatan, resiko kesehatan merokok pada remaja jauh lebih buruk dibandingkan dengan orang dewasa yang merokok karena remaja masih berada pada masa pertumbuhan. Rokok tidak hanya menyebabkan masalah pada kesehatan fisik dan juga emosional (bararah,2012). Remaja yang merokok akan terlihat lebih tua dari umurnya, kulit kering dan bergaris - garis, gigi menjadi rusak, perkembangan dan fungsi paru - paru menjadi terganggu, sesak nafas serta batuk-batuk karena banyaknya sekret di paru - paru, sistem imun tubuh menurun, resiko terkena penyakit jantung, rambut rontok dan merusak otak dan indera (Ellizabet, 2010).

Melihat kebiasaan masyarakat merokok disertai dengan tingginya prevalensi merokok dimasyarakat tidak sebanding dengan tersedianya pelayanan berhenti merokok di masyarakat. Sedangkan menurut WHO 2012, saat ini hampir 50\% dari perokok di Indonesia berpikir untuk berhenti merokok dan lebih dari 30\% dari mereka membuat upaya untuk berhenti merokok dalam 12 bulan terakhir(WHO,2012). Akan tetapi sampai saat ini belum diketahui metode yang baik untuk membantu masyarakat untuk berhenti merokok (United State Department of health and human Servise [USDHHS], 2012). Walaupun ada beberapa metode yang sudah terbukti efektif untuk membantu perokok menghentikan kebiasaan buruknya, belum ada bukti ilmiah yang menguatkan tentang efektifitas terapi berhenti merokok pada remaja (Grimshaw \& Stanton,2006). Terapinya yaitu dengan intervensi psikososial dan farmakoterapi, ini adalah dua pendekatan berhenti merokok yang sudah dilakukan pada remaja. 


\section{NURSING PRACTICES}

Mengingat bahwa sebagian besar remaja mulai merokok dibawah usia 18 tahun, dan ketergantungan nikotin bisa terjadi sejak dini, maka membantu remaja untuk berhenti merokok merupakan hal yang paling penting. Oleh karena itu,menemukan terapi yang efektif bagi remaja sangat penting. Self Help Group (SHG) atau kelompok swabantu adalah suatu kelompok yang memiliki masalah yang sama dan tiap anggotanya saling berbagi masalah baik fisik maupun emosiaonal (Ahmadi,2007). SHG merupakan suatu bentuk terapi kelompok yang dapat dilakukan pada berbagai situasi dan kondisi yang terdiri dari dua orang atau lebih yang memiliki masalah yang sama untuk saling berbagi pengalaman dan cara menghadapi masalah yang dihadapinya (Keliat et al., 2008).

Ada banyak alasan yang melatarbelakangi perilaku merokok pada remaja. Perilau merokok merupakan fungsi dari lingkungan dan individu. Perilaku merokok disebabkan oleh faktor - faktor dari dalam diri, juga disebabkan oleh faktor lingkungan. Green (1980) menyatakan bahwa perilaku seseorang termasuk perilaku merokok, dipengaruhi oleh faktor pendahulu (predisposing) yang meliputi pengetahuan, sikap, kepercayaan, keyakinan, tradisi, nilai serta faktor pemungkin (enabling) yang meliputi ketersediaan fasilitas dan faktor pendorong (reinforsing) yang meliputi sikap dan perilaku orang - orang disekitanya (Notoatmodjo, 2010)

Banyak penelitian yang menyatakan bahwa merokok dapat merusak kesehatan. Untuk itu kita dianjurkan untuk menjaga kesehatan dan dilarang menjatuhkan diri pada kebinasaan.

Sebagaiamana kaidah fiqih menyebutkan sebagai berikut:

Hukum asal sesuatu yang membahayakan adalah haram.

Menurut kaidah di atas menyebutkan bahwa segala sesuatu yang membahayakan manusia dilarang oleh syara'i termasuk di dalamnya yaitu merokok. Di mana rokok sangat membahayakan bagi manusia terutama bagi kesehatannya.
Mempertimbangkan bahaya merokok bagi kesehatan remaja, kurangnya perhatian dari pemerintah tentang pengendalian tembakau, serta tingginya prevalensi merokok pada remaja di Indonesia, maka hal ini mengindikasikan pentingnya untuk menerapkan program berhenti merokok yang efektif bagi remaja. Ditambah lagi saat ini program berhenti merokok pada remaja belum terlalu familiar di Indonesia. Dari alasan tersebut SHG dapat dilakukan untuk menjadi salah satu program untuk berhenti merokok karena SHG itu dapat merubah perilaku seseorang (Keliat et al.,2008). Apalagi salah satu alasan yang melatarbelakangi perilaku merokok pada remaja adalah sikap dan perilaku orang - orang disekitarnya (Notoatmodjo,2010), diharapkan dengan menggunakan SHG bisa merubah perilaku remaja yang merokok dengan dukungan orang-orang disekitarnya yang sama-sama perokok.

Penelitian ini dilakukan di Universitas Muhammadiyah Yogyakarta Fakultas Teknik Program Studi Teknik karena masih banyak mahasiswa yang merokok. Mahasiswa yang merokok ini dapat dilihat diarea kampus terutama di kantin kampus dan dilorong - lorong dekat kelas. Peneliti menanyakan tentang bahaya merokok dan mereka mengetahui tentang bahaya merokok dan mengerti kalau merokok itu perilaku yang buruk.

Berdasarkan uraian latar belakang, peneliti ingin mengetahui lebih lanjut apakah ada Pengaruh Self Help Group terhadap Sikap Berhenti Merokok pada Mahasiswa Teknik Mesin Universitas Muhammadiyah Yogyakarta angkatan 2015.

\section{TUJUAN PENELITIAN}

Penelitian ini bertujuan untuk mengetahui Pengaruh Self Help Group Terhadap Sikap Berhenti Merokok Pada Mahasiswa Teknik Mesin Universitas Muhammadiyah Yogyakarta Angkatan 2015.

\section{METODE PENELITIAN}

Penelitian ini menggunakan metode penelitian kuantitatif. Jenis penelitian ini menggunakan Quasy Eksperimental pretest-posttest with control group design. Penelitian ini terdapat dua kelompok, dimana kelompok perlakuan diberikan intervensi sedangkan kelompok kontrol tidak. Pada kedua kelompok perlakuan 
pretest, dan setelah diberikan intervensi diadakan pengukuran kembali (post-test). Populasi dalam penelitian ini adalah Mahasiswa perokok di Fakultas Teknik Mesin Universitas Muhammadiyah Yoyakarta Angkatan 2015 yang berjumlah 107 orang. Jumlah sampel yang diambil pada penelitian ini sebanyak $25 \%$ dari jumlah populasi sehingga didapatkan total 26 responden, 26 orang sebagai kelompok yang diberikan perlakuan dan 26 orang sebagai kelompok kontrol yang tidak diberikan perlakuan. Instrumen yang digunakan dalam penelitian ini adalah kuesioner. Analisa yang digunakan adalah analisa univariat dan analisa bivariat.

\section{HASIL DAN PEMBAHASAN}

\section{Hasil Penelitian}

1. Karakteristik Responden

Tabel 4.1. Karakteristik Responden Kelompok Intervensi dan Kelompok Kontrol

\begin{tabular}{lll}
\hline Umur & $\mathrm{F}$ & $\%$ \\
\hline Kelompok Kontrol & & \\
19 & 14 & 53,8 \\
20 & 8 & 30,8 \\
21 & 3 & 11,5 \\
22 & 1 & 3,8 \\
\hline Total & 26 & 100 \\
\hline Kelompok Intervensi & & \\
18 & 1 & 3,8 \\
19 & 15 & 57,7 \\
20 & 8 & 30,8 \\
21 & 1 & 3,8 \\
22 & 1 & 3,8 \\
\hline Total & 26 & 100 \\
\hline
\end{tabular}

Hasil tabel 4.1 menunjukkan bahwa sebagian besar responden pada kelompok kontrol berusia 19 tahun yaitu sebanyak 14 responden $(53,8 \%)$ dan responden pada kelompok intervensi sebagian besar berusia 19 tahun yaitu sebanyak 15 responden (57,8\%).

2. Distribusi Frekuensi Sikap Berhenti Merokok pada Mahasiswa Teknik Mesin Universitas Muhammadiyah Yogyakarta angkatan 2015 Kelompok Kontrol dan Kelompok Intervensi.

Hasil tabel 4.2 menunjukkan bahwa sebagian besar respoden pada kelompok pretest kontrol mendukung sikap berhenti merokok sebanyak18 responden $(69,2)$ dan pada kelompok postest kontrol meningkat menjadi 5 responden $(96, \%)$ sedangkan sebagian besar respoden pada kelompok pretest intervensi mendukung sikap berhenti merokok sebanyak 25 responden $(96,2)$ dan pada kelompok postest kontrol meningkat menjadi 26 responden (100\%)

Tabel 4.2. Distribusi Frekuensi Sikap Berhenti Merokok pada Mahasiswa Teknik Mesin

\begin{tabular}{lllll}
\hline Kelompok & \multicolumn{1}{l}{ Kontrol } & \multicolumn{3}{l}{ Intervensi } \\
\hline Sikap Mahasiswa & F & $\%$ & F & $\%$ \\
\hline Pretest & 18 & 69,2 & 25 & 96,2 \\
Mendukung & 8 & 30,8 & 1 & 3,8 \\
Tidak Mendukung & & & & \\
\hline Total & 26 & 100 & 26 & 100 \\
\hline Postest & 25 & 96,2 & 26 & 100 \\
Mendukung & 1 & 3,8 & 0 & 0 \\
Tidak Mendukung & & & & \\
\hline Total & 26 & 100 & 26 & 100 \\
\hline
\end{tabular}

\section{Pengaruh Self Help Group terhadap sikap} mahasiswa tentang berhenti merokok pada kelompok kontrol dan intervensi.

Tabel 4.3 menunjukkan bahwa dengan menggunakan uji wilcoxon didapakan nilaip value $<0,05$. Sehingga terdapat pengaruh yang signifikan sebelum dan setelah dilakukan Self Help Group terhadap sikap mahasiswa tentang berhenti merokok pada kelompok kontrol dan kelompok intervensi.

Tabel 4.3. Pengaruh Self Help Group terhadap sikap mahasiswa tentang berhenti merokok pada kelompok kontrol dan intervensi

\begin{tabular}{lll} 
& $\begin{array}{l}\text { Post Kontrol - Pre } \\
\text { Kontrol }\end{array}$ & $\begin{array}{l}\text { Post Intervensi - Pre } \\
\text { Intervensi }\end{array}$ \\
\hline Z & $-4,390^{\mathrm{a}}$ & $-4,464^{\mathrm{a}}$ \\
\hline Asymp. Sig. (2-tailed) &, 000 &, 000
\end{tabular}

4. Pengaruh Self Help Group terhadap sikap mahasiswa tentang berhenti merokok pada kelompok Pretest Intervensi-Pretest Kontrol

Tabel 4.4 menunjukkan bahwa dengan menggunakan uji Mann-Withney didapakan nilai $\mathrm{p}$ 


\section{NURSING PRACTICES}

value $0,134>0,05$. Sehingga tidak ada pengaruh yang signifikan antara pretest kelompok intervensi dan kelompok kontrol sebelum dilakukan Self Help Group terhadap sikap mahasiswa tentang berhenti merokok.

Tabel 4.4. Pengaruh Self Help Group terhadap sikap mahasiswa tentang berhenti merokok pada kelompok Pretest Intervensi-Pretest Kontrol

\begin{tabular}{ll} 
& Kod.Pre.Intervensi \\
\hline Mann-Whitney U & 63,000 \\
\hline Wilcoxon W & 234,000 \\
\hline Z & $-1,500$ \\
\hline Asymp. Sig. (2-tailed) &, 134 \\
\hline Exact Sig. [2*(1-tailed Sig.)] &, $644^{\mathrm{a}}$
\end{tabular}

5. Pengaruh Self Help Group terhadap sikap mahasiswa tentang berhenti merokok pada kelompok Posttest Intervensi-Posttest Kontrol

Tabel 4.5. Pengaruh Self Help Group terhadap sikap mahasiswa tentang berhenti merokok pada kelompok Posttest Intervensi-Posttest Kontrol

\begin{tabular}{ll} 
& Kod.Post.Intervensi \\
\hline Mann-Whitney U & 12,500 \\
\hline Wilcoxon W & 13,500 \\
\hline Z & $-1,000$ \\
\hline Asymp. Sig. (2-tailed) & 1,000 \\
\hline Exact Sig. [2*(1-tailed Sig.)] & $1,000^{\mathrm{a}}$
\end{tabular}

Tabel 4.5 menunjukkan bahwa dengan menggunakan uji Mann-Withney didapakan nilai p value $1.000>0,05$. Sehingga tidak ada pengaruh yang signifikan antara postest kelompok intervensi dan postest kelompok kontrol sebelum setelahSelf Help Group terhadap sikap mahasiswa tentang berhenti merokok

\section{PEMBAHASAN}

\section{Karakteristik Responden}

Berdasarkan hasil penelitian bahwa karakteristik umur responden sebagian besar adalah responden dengan umur 19 tahun. pada kelompok kontrol berusia 19 tahun yaitu sebanyak 14 responden $(53,8 \%)$ dan responden pada kelompok intervensi sebagian besar berusia 19 tahun yaitu sebanyak 15 responden $(57,8 \%)$. Umur responden pada penelitian ini berkisar antara 1822 tahun yang masih tergolong remaja pertengahan dan remaja akhir. Untuk remaja akhir seorang anak biasanya cendrung mulai melakukan pengungkapan kebebasan dalam dirinya dan lebih banyak bergaul dengan dengan teman sebaya diluar rumah sehingga berpotensi membuat anak cendrung untuk merokok (Amelia,2009).

Umur sangat mempengaruhi bagaimana responden mengambil keputusan dalam hal mengkosumsi rokok atau tidak, karena semakin bertambahnya umur maka pengalaman dan pengetahuan seseorang semakin bertambah (Notoatmodjo,2010). Menurut Rahmadi et al. (2013), remaja mulai merokok dikarenakan kurangnya aturan dari orang tua. Mereka mencoba pertama kali merokok sebelum usia 10 tahun. Penentu remaja merokok adalah pengaruh orang tua,saudara dan teman sebaya. Pengaruh masyarakat yang didominasi oleh perokok juga berpengaruh terhadap perilaku remaja untuk memulai merokok. Hal ini juga dipengaruhi karena pada usia remaja mereka mencoba mengeksplorasi peran mereka. Orang tua berpengaruh dalam memberi pola asuh dan menentukan pola asuh seperti orang tua yang memberikan uang saku berlebihan dan mendukung orang tua dalam perilaku merokok yang sangat kurang.

Pada mahasiswa Teknik Mesin angkatan 2015 didapatkan seluruh respondennya berjenis kelamin laki-laki. Mahasiswa teknik mesin 2015 merupakan sasaran utama untuk dijadikan sebagai responden penelitian mengenai rokok karena mereka masih sangat rentan, rendahnya pengetahuan mengenai rokok dan mudah terpengaruh oleh dengan kondisi yang ada dilingkungan sekitarnya (KEMENKES,2012). Jumlah perokok paling banyak saat ini berasal dari kalangan laki-laki yaitu mencapai $61 \%$. Hal ini dikarenakan pengaulan dan tekanan dari lingkungan. Remaja pada usia ini sangat cepat menerima informasi yang didapat dan diaplikasikan kedalam kehidupan nyata (Aditama,2004). Dalam Self Help Group mahasiswa dibantu untuk mendapatkan informasi yang positif dengan memberitahukan kerugian-kerugian yang dialami serta mendapat pengalaman dari teman-teman yang bisa menyelesaikan masalahnya.

Data yang diperoleh peneliti sesuai dengan data RISKESDAS mengenai prevalensi konsumsi tembakau 
penduduk berdasarkan umur $>15$ tahun di Indonesia pada tahun 2013 yaitu laki-laki lebih dominan n64,9\% dan perempuan 2,1\% (TCSCIAKMI,2014).

\section{Pengaruh Self Help Group Terhadap Sikap Mahasiswa Tentang Berhenti Merokok}

Hasil penelitian menunjukkan sikap mahasiswa berhenti merokok di mahasiswa teknik mesin sebelum diberikan Self-Help Group yaitu yang mendukung 25 orang (96,2\%) dan tidak mendukung 1 orang (3,8\%). Hasil uji beda pada nilai mean yang meningkat menunjukkan bahwa terdapat pengaruh yang signifikan terhadap tiap kelompok perlakuan $(p=0.000)$. Hal tersebut dikarenakan banyak faktor yang mempengaruhinya. Berdasarkan kuesioner yang telah dibagikan bahwa faktor keluarga dan faktor teman yang lebih banyak mempengaruhi sikap remaja untuk merokok ( Musaeni,2011).

Terdapat perbedaan yang signifikan pada sikap sikap mahasiswa sebelum dilakukan intervensi dan setelah dilakukan intervensi atau sikap mahasiswa mendukung setelah diberikan SHG. Sikap adalah suatu penilaian atau pendapat seseorang terhadap stimulus atau objek (masalah kesehatan, termasuk penyakit). Sikap yang terdapat pada individu akan memberikan warna atau perbuatan individu yang bersangkutan.

Sebagian besar tindakan individu ditentukan bagaiman individu membentuk dunianya. Berbagai pikiran yang dimiliki individu ditentukan oleh bagaimana sikap dan reaksinya (Efendi,2005). Sikap dapat diartikan sebagai suatu respon yang tertutup dari seseorang yang tidak dapat dilihat secara langsung. Sikap seseorang bisa menjadi pondasi yang kuat untuk membentuk perilaku. Baik buruknya perilaku seseorang ditentukan oleh sikap seseorang terhadap situasi yang dihadapi. Jadi, membentuk sikap yang positif mungkin diperlukan untuk membentuk suatu kepribadian serta perilaku yang baik.

Self-Help Group memiliki kualitas yang lebih positif karena SHG ini berkaitan dengan hubungan sosial. Tercapainya tujuan yang diinginkan dalam SelfHelp Group yang ditentukan dinamika kelompok itu sendiri. Jika dinamika utama dalam Self-Help Group itu adalah jika kekuatan hubungan interpersonal kurang, maka tujuan kelompok tidak akan tercapai. Sebaliknya, jika hubungan interpersonal dari masing-masing anggota kelompok terjalin dengan baik, anggota saling mendukung satu sama lainnya maka tujuannya akan tercapai. Keberhasilan dari Self-Help Group itu dapat dilihat dari tercapainya tujuan kelompok yang diharapkan (Chamberlin \& Roger, 1990).

Dalam Self-Help Group peserta dapat mengeksplor perasaannya dan menceritakan masalah-masalah yang mereka hadapi tentang rokok. Melalui SHG responden dapat berbagi pengalaman dan berbagi informasi yang nereka dapatkan yang dapat mempengaruhi sikap dan pengetahuan responden terhadap rokok. Sikap seseorang dapat dipengaruhi oleh pengalaman pribadi, pengaruh orang lain yang dianggap penting, pengaruh budaya, media massa, serta faktor emosional (Azwar,2011).

\section{Pengaruh Self-Help GroupTerhadap Sikap Berhenti Merokok Pada Kelompok Intervensi Pre -Test dan Post-Test}

Hasil penelitian menunjukkan bahwa dengan menggunakan uji wilcoxon tentang perbedaan nilai pre-test dan pos-test didapakan nilai signifikansi 0,000 $(p<0,05)$. Sehingga terdapat pengaruh yang signifikan terhadap peningakatan sikap berhenti merokok pada mahasiswa setelah diberikan SHG. Dengan kata lain, kelompok intervensi memiliki nilai sikap yang tinggi karena kelompok intervensi mendapat perlakuan SHG.

Pada kelompok perlakuan sebelum diberikan intervensi didapatkan hasil bahwa 1 orang $(3,8 \%)$ yang tidak mendukung hal ini dikarenakan belum diberikan intervensi dengan melakukan diskusi sesama orang yang mempunyai masalah mengenai rokok.

Pada kelompok perlakuan setelah diberikan intervensi berupa Self Help Group atau melakukan diskusi antara sesama orang yang memiliki masalah rokok, didapatkan hasil bahwa Self Help Group memiliki pengaruh yang signifikan terhadap sikap berhenti merokok pada mahasiswa teknik mesin. Setelah diberikan intervensi respoden pada kelompok postest intervensi meningkat menjadi 26 responden (100\%). Penelitian ini dalam kelompok intervensi mendapat perlakuan SHG dimana dalam SHG mahasiswa dibantu untuk mendapatkan 


\section{NURSING PRACTICES}

informasi yang positif dan memberitahukan kerugiankerugian yang dialami serta pengalaman dari temanteman lainnya yang merokok. Hal ini didukung dengan penelitian dari mafika (2011) yang menyatakan bahwa terdapat pengaruh teman sebaya (Peer Education) terhadap peningkatan sikap untuk tidak merokok baik dirumah maupun diluar rumah.

Penelitian ini didukung dengan penelitian Ekawati (2012), menyatakan bahwa terdapat peningkatan sikap setelah dilakukan SHG atau kelompok swabantu pada remaja. Menurut penelitian Lizam (2009), yang menyatakan bahwa terdapat perubahan sikap yang positif terhadap sikap tidak merokok dan kecendrungan untuk berhenti merokok setelah dilakukan diskusi kelompok sesama perokok.

Intervensi dalam penelitian ini menggunakan Self Help Group dimana dalam kelompok ini dikumpulkan orang-orang yang memiliki permasalahn yang sama dengan tujuan agar mereka dapat bertukar pikiran, saling berbagi pengalaman dan terbuka antar kelompok. Apabila terdapat permasalahan dapat terpecahkan bersama sehingga penelitian memperoleh peningkatan sikap setelah diberikan SHG. Hal ini didukung dengan pernyataan bahwa sikap merupakan reaksi atau respon yang masih tertutup terhadap stimulus atau objek dan sikap sering diperoleh dengan pengalaman sendiri atau pengalaman orang lain yang paling dekat (Notoatmodjo, 2010).

Menurut penelitian yang dilakukan oleh Gayatri at al.(2009) mengatakan bahwa Self Help Group telah terbukti cukup efektif dalam menanggani masalah dan meningkatkan koping keluarga. Efektifitasnya kelompok-kelompok berasal dari beberapa pernyataan, yaitu pertama, bahwa dukungan emosional dari orang lain dapat mengurangi isolasi sosial yang dialami oleh banyak orang dengan kondisi kronis. Kedua,dapat memunculkan identitas diri seseorang yang kolektif melalui partisipasi kelompok, tiap anggota kelompok juga dapat mengembangkan konsep baru yang didapatkan pada dirinya sendiri. Ketiga, partisipasi antar anggota kelompok memungkinkan untuk berbagi pengetahuan, pengalaman dan saran untuk mengatasi masalah yang dihadapinya.
Salah satu faktor yang mempengaruhi sikap seseorang untuk merokok yaitu teman sebaya, keluarga, pengetahuan, media massa. Hal ini dapat dilihat pada kelompok perlakuan pada saat melakukan Self Help Group responden mengatakan bahwa faktor teman lah yang paling banyak mempengaruhi mereka untuk merokok dan dari hasil evaluasi bahwa dari 26 responden didapatkan 13 orang (50\%) yang merokok karena faktor teman sebaya. Pernyataan ini didukung oleh Amelia (2009) bahwa Untuk remaja akhir seorang anak biasanya cendrung mulai melakukan pengungkapan kebebasan dalam dirinya dan lebih banyak bergaul dengan dengan teman sebaya diluar rumah sehingga berpotensi membuat anak cendrung untuk merokok.

Selain faktor teman, keluarga juga sangat mempengaruhi sikap remaja untuk berhenti merokok. Remaja dengan orang tuanya seorang perokok akan berisiko tinggi untuk merokok apabila kurang aturan dari orang tua dan lingkungannya yang tidak memberikan dukungan yang positif. Dari pernyataan responden saat melakukan Self Help Group bahwa keluarga dan lingkungan yang paling mempengaruhi untuk merokok, seorang anak yang biasanya mengikuti pola orang tuanya. Dan dari hasil evaluasi dari 26 responden didapatkan 20 responden (76,9\%) yang merokok karena dipengaruhi oleh keluarga. Hal ini didukung dengan pernyataan bahwa remaja mulai merokok dikarenakan kurangnya aturan dari keluarga termasuk orang tua. Mereka mencoba pertama kali merokok sebelum usia 10 tahun. Penentu sikap remaja untuk berhenti merokok adalah dukungan orang tua yang sangat penting (Rahmadi,2013).

Berdasarkan hasil evaluasi dari 26 responden didapatkan 9 responden $(34,6 \%)$ yang menyatakan bahwa merokok dapat menghilangkan strees. Dalam penelitian Amelia (2009) menyatakan bahwa perilaku merokok pada laki-laki lebih tinggi dibandingkan dengan perempuan. Hal ini berkaitan dengan stress yang dialami laki-laki. Remaja pada umumnya memiliki tingkat stress yang sama tapi ketika laki-laki mengalami stress mereka cendrung menunjukkan perilaku yang agresif sehingga melakukan hal-hal yang negatif seperti merokok. 
Levental dan Clearly (dalam Sukma,2011) mengungkapkan terdapat empat tahap dalam perilaku merokok sehingga seseorang menjadi perokok, yaitu: Tahap perpatory, seseorang mendapatkan gambaran yang menyenangkan mengenai merokok dengan cara mendengar, melihat atau dari hasil bacaan. Hal-hal ini menimbulkan minat untuk merokok. Tahap initiation, tahap perintisan merokok yaitu tahap apakah seseorang akan meneruskan atau tidak terhadap perilaku merokok. Tahap becoming a smoker, apabila seseorang telah mengkonsumsi rokok sebanyak empat batang perhari maka mempunyai kecendrungan menjadi perokok. Tahap maintenance of smoking, tahap ini merokok sudah menjadi salah satu bagian dari cara pengaturan diri (self regulating). Merokok dilakukan untuk memperoleh efek psikologis yang menyenangkan (Aula,2010).

Berdasarkan pernyataan responden pada saat melakukan Self Help Group mengenai adanya zat-zat berbahaya dalam rokok yang berisiko terkena kanker paru-parusebagian responden mengatakan bahwa mereka akan berhenti merokok. Dan dari hasil evaluasi dari 26 responden didapatkan 22 responden $(84,6 \%)$ akan berhenti merokok karena mengingat adanya zat-zat yang berbahaya didalam rokok yang akan menyebabkan terjadinya kanker paru-paru. Pernyataan ini di dukung oleh penelitian Virly (2013) menyatakan bahwa Merokok akan menimbulkan masalah kesehatan, seperti gangguan jantung, stroke, kanker paru-paru dan masalah kesehatan lainnya. Permasalahan saat ini terletak pada proses yang salah yaitu proses pembakaran yang mengubah tembakau menjadi racun dan rokok adalah jendela awal terjadinya penggunaan narkoba. Akibat kronik yang dikhawatirkan dari penggunaan nikotin adalah ketergantungan. Sekali saja seseorang mencoba menjadi perokok, maka dia akan sulit untuk mengakhiri kebiasaan itu, baik secara fisik maupun psikologis.

Merokok bila dilihat dari berbagai aspek sangat merugikan, baik bagi diri perokok itu sendiri maupun orang yang disekitanya yang terpapar asap rokok dan hampir setiap saat dapat kita temui dan lihat orang yang merokok. Saat ini perilaku merokok dianggap sangat wajar dipandang oleh remaja khususnya remaja laki-laki. perilaku merokok pada remaja umumnya semakin lama semakin meningkat sesuai dengan tahap perkembangan yang ditandai dengan peningkatan frekuensi dan intensitas merokok dan sering mengakibatkan seorang yang merokok ketergantungan akan nikotin (Ariani \& Margawati, 2011).

Zaman moderenisasi, banyak hal yang dilakukan untuk berhenti merokok. Berhenti merokok dapat dilaksanakan dengan berbagai cara, yaitu dengan cara farmakologi, informasi non-sosial, Dukungan suportif interpersonal dan membentuk kelompok kecil sukarela. Kelompok kecil sukarela itu adalah Self Help Group. Self Help Group (SHG) atau Kelompok swabantu adalah suatu kelompok yang umumnya dibentuk oleh individu yang sebaya, yang telah datang bersama-sama untuk saling membantu dalam memenuhi kebutuhan umum, seperti mengatasi masalah yang menganggu mereka (Keliat,2008). Self Help Group lebih berorientasi pada perubahan kognitif dan perilaku, dimana setiap anggota belajar dari perilaku yang adaptif melalui proses berbagi pengalaman antar sesama anggota kelompok yang terdiri dari 7-10 orang dengan waktu 60-120 menit yang digunakan untuk diskusi (Huriah,2012).

Self Help Group merupakan salah satu program berhenti merokok yang lebih berorientasi pada perubahan perilaku seseorang yang harus di ikuti dengan adanya niat,minat, semangat dan keinginan yang kuat untuk mengubahnya. Keberhasilan dari membentuk kelompok suka rela ini ditentukan dengan adanya keinginan, niat dan minat yang disertai akan dengan adaya bukti yang realistis yang harus dimiliki oleh partisipan sehingga proporsi droup-out nya dapat terminimalisir ( Ashfrod \& Lecroy, 2009; Zastrow, 2008). Pada dasarnya orang - orang dengan isolasi sosial akan lebih cendrung memilih dukungan sosial ini karena Self Help Group dapat menjadi sumber dukungan sosial yang signifikan, dan anggota kelompoknya dapat menuangkan isi hatinya, mengungkap masalahnya dan anggota yang lain menanggapi, memberikan saran atau cara untuk mengatasi masalahnya. Dalam pelaksanaan swabantu ini ada beberapa orang yang berperan penting sebagai pemimpin (leader), anggota kelompok dan 


\section{NURSING PRACTICES}

fasilitator. Fasilitator dalam diskusi ini adalah seorang tenaga kesehatan yang tugasnya akan mebimbing atau memantau pelaksanaan Self Help Group, memberikan penjelasan dan memotivasi anggota kelompok untuk mengeluarkan pendapatnya (Keliat at al.2008).

Pada penelitian yang dilakukan oleh Park, et al. (2012) menyebutkan bahwa keefektifan beberapa intervensi untuk pengontrolan tembakau dapat dilakukan dalam rentang waktu 50 menit sampai dengan 1,5 jam setiap sesinya dalam 4-8 minggu. Pada kelompok swabantu ini memiliki kualitas yang sangat positif karena berkaitan dengan hubungan sosial. Tercapainya sutu tujuan dalam kelompok didasarkan kelompok itu sendiri, dalam Self Help Group jika kekuatan hubungan interpersonal dan anggota kelompok kurang maka tujuan kelompok juga kemungkinan tidak akan tercapai. Sebaliknya jika dalam kelompok hubungan interpersonal dan anggota kelompoknya saling mendukung maka tujuan kelompoknya akan tercapai karena kekompakan dan adanya dukungan sosial sangat dibutuhkan dan merupakan suatu faktor penetu dari kesuksesan usaha untuk berhenti merokok (Brockman, at al.,2014).

Kelompok-kelompok swadaya ini didasarkan pada sekelompok individu yang akan berbagi perilaku, kemudian mereka dapat mengidentifikasikan berbagai permasalahan kemudian dapat saling mendukung, mengendalikan atau menghilangkan perilaku dan sikap tersebut. Dalam Self Help Group setiap anggota bisa mengungkapkan isi pikirannya terhadap apa yang dibahas, membicarakan pengalaman masing-masing. Peserta ataupun anggota juga akan mendapatkan saran dan dukungan dari anggota lainnya, hal inilah yang akan memberikan semangat bagi peserta (Knight,2006).

\section{Pengaruh Self-Help Group Terhadap Sikap Berhenti Merokok Pada Kelompok Kontrol Pre -Test dan Post-Test.}

Hasil penelitian menunjukkan bahwa dengan menggunakan uji wilcoxon tentang perbedaan nilai pre-test dan pos-test pada kelompok kontrol didapakan nilai signifikansi $0,000(p<0,05)$. Sehingga terdapat pengaruh yang signifikan terhadap peningakatan sikap berhenti merokok pada mahasiswa setelah diberikan leflet. Dengan kata lain, kelompok kontrol memiliki nilai sikap yang tinggi sama dengan kelompok intervensi.

Pada kelompok kontrol di Mahasiswa Teknik Mesin Angkatan 2015 sebelum diberikan leflet menunjukkan bahwa terdapat 8 responden $(30,8 \%)$ yang tidak mendukung dan yang mendukung 18 responden (69,2\%).

Pada kelompok kontrol setelah diberikan leflet jumlah responden yang mendukung meningkat dari 18 responden $(69,2 \%)$ menjadi 25 responden $(96,2 \%)$.

\section{Pengaruh Self Help Group Terhadap Sikap Mahasiswa Tentang Berhenti Merokok pada kelompok intervensi pre-test dan pos-test}

Hasil penelitian menunjukkan bahwa dengan menggunakan uji wilcoxon tentang perbedaan nilai pre-test dan pos-test didapakan nilai signifikansi 0,000 $(p<0,05)$. Sehingga terdapat pengaruh yang signifikan terhadap peningakatan sikap berhenti merokok pada mahasiswa stelah diberikan SHG. Dengan kata lain, kelompok intervensi memiliki nilai sikap yang tinggi karena kelompok intervensi mendapat perlakuan SHGsebelum dan setelah dilakukan Self Help Group terhadap sikap mahasiswa tentang berhenti merokok pada kelompok intervensi. Sebelum menjadi perokok, seseorang melalui beberapa tahapan yang dilaluinya terlebih dahulu. Levental dan Clearly (dalam Sukma, 2011) mengungkapkan terdapat empat tahap dalam perilaku merokok sehingga seseorang menjadi perokok, yaitu: Tahap perpatory, seseorang mendapatkan gambaran yang menyenangkan mengenai merokok dengan cara mendengar, melihat atau dari hasil bacaan. Hal-hal ini menimbulkan minat untuk merokok. Tahap initiation, tahap perintisan merokok yaitu tahap apakah seseorang akan meneruskan atau tidak terhadap perilaku merokok. Tahap becoming a smoker, apabila seseorang telah mengkonsumsi rokok sebanyak empat batang perhari maka mempunyai kecendrungan menjadi perokok. Tahap maintenance of smoking, tahap ini merokok sudah menjadi salah satu bagian dari cara pengaturan diri (self regulating). Merokok dilakukan untuk memperoleh efek psikologis yang menyenangkan (Aula,2010). 
Menurut penelitian yang dilakukan oleh Gayatri at al.(2009) mengatakan bahwa Self Help Group telah terbukti cukup efektif dalam menanggani masalah dan meningkatkan koping keluarga. Efektifitasnya kelompok-kelompok berasal dari beberapa pernyataan, yaitu pertama, bahwa dukungan emosional dari orang lain dapat mengurangi isolasi sosial yang dialami oleh banyak orang dengan kondisi kronis. Kedua, dapat memunculkan identitas diri seseorang yang kolektif melalui partisipasi kelompok, tiap anggota kelompok juga dapat mengembangkan konsep baru yang didapatkan pada dirinya sendiri. Ketiga, partisipasi antar anggota kelompok memungkinkan untuk berbagi pengetahuan, pengalaman dan saran untuk mengatasi masalah yang dihadapinya.

Self Help Group lebih berorientasi pada perubahan perilaku seseorang yang harus di ikuti dengan adanya niat,minat, semangat dan keinginan yang kuat untuk mengubahnya. Keberhasilan dari membentuk kelompok suka rela ini ditentukan dengan adanya keinginan, niat dan minat yang disertai akan dengan adaya bukti yang realistis yang harus dimiliki oleh partisipan sehingga proporsi droup-out nya dapat terminimalisir ( Ashfrod \& Lecroy, 2009; Zastrow, 2008). Pada dasarnya orang - orang dengan isolasi sosial akan lebih cendrung memilih dukungan sosial ini karena Self Help Group dapat menjadi sumber dukungan sosial yang signifikan, dan anggota kelompoknya dapat menuangkan isi hatinya, mengungkap masalahnya dan anggota yang lain menanggapi, memberikan saran atau cara untuk mengatasi masalahnya. Dalam pelaksanaan swabantu ini ada beberapa orang yang berperan penting sebagai pemimpin (leader), anggota kelompok dan fasilitator. Fasilitator dalam diskusi ini adalah seorang tenaga kesehatan yang tugasnya akan mebimbing atau memantau pelaksanaan Self Help Group, memberikan penjelasan dan memotivasi anggota kelompok untuk mengeluarkan pendapatnya (Keliat at al.2008).

Pada penelitian yang dilakukan oleh Park, et al. (2012) menyebutkan bahwa keefektifan beberapa intervensi untuk pengontrolan tembakau dapat dilakukan dalam rentang waktu 50 menit sampai dengan 1,5 jam setiap sesinya dalam 4-8 minggu. Pada kelompok swabantu ini memiliki kualitas yang sangat positif karena berkaitan dengan hubungan sosial. Tercapainya sutu tujuan dalam kelompok didasarkan kelompok itu sendiri, dalam Self Help Group jika kekuatan hubungan interpersonal dan anggota kelompok kurang maka tujuan kelompok juga kemungkinan tidak akan tercapai. Sebaliknya jika dalam kelompok hubungan interpersonal dan anggota kelompoknya saling mendukung maka tujuan kelompoknya akan tercapai karena kekompakan dan adanya dukungan sosial sangat dibutuhkan dan merupakan suatu faktor penetu dari kesuksesan usaha untuk berhenti merokok (Brockman, at al.,2014).

\section{Pengaruh Self Help Group terhadap sikap mahasiswa tentang berhenti merokok pada kelompok Pretest Intervensi-Pretest Kontrol dan pada kelompok Posttest Intervensi-Posttest Kontrol}

Hasil penelitian menunjukkan bahwa dengan menggunakan uji Mann-Withney didapakan nilai $p$ value $0,134>0,05$. Sehingga tidak ada pengaruh yang signifikan antara pretest kelompok intervensi dan kelompok kontrol sebelum dilakukan Self Help Group terhadap sikap mahasiswa tentang berhenti merokok. Hasil penelitian jua menunjukkan bahwa dengan menggunakan uji Mann-Withney didapakan nilai $p$ value $1.000>0,05$. Sehingga tidak ada pengaruh yang signifikan antara postest kelompok intervensi dan postest kelompok kontrol sebelum setelah Self Help Group terhadap sikap mahasiswa tentang berhenti merokok.

Zaman moderenisasi, banyak hal yang dilakukan untuk berhenti merokok. Berhenti merokok dapat dilaksanakan dengan berbagai cara, yaitu dengan cara farmakologi, informasi non-sosial, Dukungan suportif interpersonal dan membentuk kelompok kecil sukarela . Kelompok kecil sukarela itu adalah Self Help Group. Self Help Group (SHG) atau Kelompok swabantu adalah suatu kelompok yang umumnya dibentuk oleh individu yang sebaya, yang telah datang bersama-sama untuk saling membantu dalam memenuhi kebutuhan umum, seperti mengatasi masalah yang menganggu mereka (Keliat,2008). Self Help Group lebih berorientasi pada perubahan kognitif dan perilaku, dimana setiap anggota 


\section{NURSING PRACTICES}

belajar dari perilaku yang adaptif melalui proses berbagi pengalaman antar sesama anggota kelompok yang terdiri dari 7-10 orang dengan waktu 60-120 menit yang digunakan untuk diskusi (Huriah,2012).

Kelompok-kelompok swadaya ini didasarkan pada sekelompok individu yang akan berbagi perilaku, kemudian mereka dapat mengidentifikasikan berbagai permasalahan kemudian dapat saling mendukung, mengendalikan atau menghilangkan perilaku dan sikap tersebut. Dalam Self Help Group setiap anggota bisa mengungkapkan isi pikirannya terhadap apa yang dibahas, membicarakan pengalaman masing-masing. Peserta ataupun anggota juga akan mendapatkan saran dan dukungan dari anggota lainnya, hal inilah yang akan memberikan semangat bagi peserta (Knight,2006).

\section{KESIMPULAN DAN SARAN}

Hasil penelitian menunjukkan bahwa sebagian besar responden pada kelompok kontrol berusia 19 taahun yaitu sebanyak 14 responden $(53,8 \%)$ dan responden pada kelompok intervensi sebagian besar berusia 19 tahun yaitu sebanyak 15 responden (57,8\%). Hasil penelitian menunjukkan bahwa sebagian besar respoden pada kelompok pretest kontrol mendukung sikap berhenti merokok sebanyak18 responden $(69,2)$ dan pada kelompok postest kontrol meningkat menjadi 5 responden $(96, \%)$ sedangkan sebagian besar respoden pada kelompok pretest intervensi mendukung sikap berhenti merokok sebanyak 25 responden $(96,2)$ dan pada kelompok postest kontrol meningkat menjadi 26 responden (100\%). Hasil penelitian menunjukkan bahwa dengan menggunakan uji wilcoxon didapakan nilai $p$ value $<0,05$. Sehingga terdapat pengaruh yang signifikan sebelum dan setelah dilakukan Self Help Group terhadap sikap mahasiswa tentang berhenti merokok pada kelompok kontrol dan kelompok intervensi. Hasil penelitian menunjukkan bahwa dengan menggunakan uji Mann-Withney didapakan nilai $\mathrm{p}$ value 0,134 > 0,05 . Sehingga tidak ada pengaruh yang signifikan antara pretest kelompok intervensi dan kelompok kontrol sebelum dilakukan Self Help Group terhadap sikap mahasiswa tentang berhenti merokok. Tabel 4.5 menunjukkan bahwa dengan menggunakan uji
Mann-Withney didapakan nilai $p$ value $1.000>0,05$. Sehingga tidak ada pengaruh yang signifikan antara postest kelompok intervensi dan postest kelompok kontrol sebelum setelah Self Help Group terhadap sikap mahasiswa tentang berhenti merokok.

\section{DAFTAR PUSTAKA}

Ariani, R. D.,Margawati,A.(2011). Hubungan Antara Iklan Dengan Sikap Dan Perilaku Merokok Pada Remaja (SMA Negeri 4 Semarang). Program Pendidikan Sarjana Kedokteran Fakultas Kedokteran Universitas Diponegoro.

Arikunto, S. (2010). Prosedur Penelitian Suatu Pendekatan Praktek. Jakarta: Rineka Cipta

Badan Pusat Statistik. (2010). Statistik Pemuda Provinsi DI. Yogyakarta 2010. Yogyakarta

Badan Pusat Statistika. (2012). Indikator Pembangunan Berkelanjutan 2012. Jakarta

Bhanji, S., Andrades, M., Taj, F., Khuwaja, A. K. (2011). Factors Related To Knowledge And Perception Of Women About Smoking: A Cross Sectional Study From A Developing Country.

Brockman, L. N,. Christakis. D A,. \& Moreno,. M A,. (2014). Friending Adolescents on Sosial Networking Websites: A Feasible Reseach Tool. Journal of interaction science, 2(1),10.1186/2194-0827-2-1. Diakses 5 Desember 2015, dari http://www.ncbi.nlm.nih.gov/pmc/articles/ PMCC4255910.

Departemen Kesehatan Republik Indonesia. (2012). Kemenkes Luncurkan Hasil Survey Tembakau. Jakarta. Diakses pada tanggal 4 Desember 2015 dari http:// www.depkes.go.id/index.php/berita/pres-release/2048kemenkes-luncurkan-hasil-survey-tembakau.html.

Depkes. (2013). Kemenkes luncurkan survey tembakau diakses 25 november 2015 dari http://www.depkes. go.id/index.php?vw=2\&id=2048

Elma ,Huda; Haddad, Linda; Alzyoud, Sukaina et al.(2011). Knowledge, Attitudes, and Behavior in Avoiding Secondhand Smoke Exposure Among Non-Smoking Employed Women with Higher Education in Jordan. Int. J. Environ. Res. Public Health 8 : 4207-4219.

Febriani, Tria (2014). Pengaruh Persepsi Mahasiswa Terhadap Kawasan Tanpa Rokok (KTR) dan Dukungan 
penerapannya di Universitas Sumatera Utara. Karya Tulis Ilmiah stara satu Universitas Sumatera Utara,Sumatera. Gayatri Dewi., Keliat Anna Budi.,Sutini.(2009). Pengaruh Terapi Self Help Group terhadap Koping Keluarga dengan Anak Retardasi Mental di SLB Kabupaten Sumedang (Tesis). Depok: Universitas Indonesia.

Gerungan. (2009). Psikologi sosial bandung: Refika Aditama. Haryoko, S. (2009). Efektifitas Pemanfaatan Media AudioVisual Sebagai Alternatif Optimalisasi Model Pembelajaran. Jurnal Edukasi. Diakses 5 Oktober 2013, dari journal.uny.ac.id/index.php/jee/article/ download/972/781.

Hasanah, A.U \& Sulastri. (2011). Hubungan Antara Dukungan Orang Tua, Teman Sebaya dan Iklan Rokok dengan Perilaku Merokok pada Siswa Laki-Laki Madrasah Aliyah Negeri 2 Boyolali. Gaster, 8 (1), 695 705.

Huriah. (2012). Analisis Faktor yang Mempengruhi perilaku Merokok pada Mahasiswa Fakultas Siswa SMK Kesatrian Solo Kartasura Sukoharjo. The Soedirman Journal of Nursing, Volume 6, No.

Ilyas, Y. 2010. Muhammadiyah Merokok Haram. Diakses tgl

1 Desember 2015 dari www.kompas.com

Kemenkes, RI. (2013). Melindungi Generasi Bangsa dari Iklan, Promosi dan Sponsor Rokok, Menkes Luncurkan Peraturan Pencantuman Peringatan dan Informasi Kesehatan pada Kemasan Rokok. (Online)(http:// www.depkes.go.id/index.php? vw=2\&id=2310) Diakses 13 November 2015

Kemenkes, RI. (2013). Melindungi Generasi Bangsa dari Iklan, Promosi dan Sponsor Rokok, Menkes Luncurkan Peraturan Pencantuman Peringatan dan Informasi Kesehatan pada Kemasan Rokok. (Online). Diakses 13 November 2015 dari http://www.depkes.go.id/index. php? ${ }_{\mathrm{vw}}=2$ \& $\mathrm{id}=2310$.

Knight., Hafeez Qadri, Majid., Fatima, Kiran., et al.(2006). A Community Based Study about Knowledge and Practices Regarding Tobacco Consumption and Passive Smoking in Gadap Town, Karachi.JPMA 57 (4):186-188.

Komalasari, D., Helmi, A. F. (2000). Faktor-Faktor Penyebab Perilaku Merokok pada Remaja. Jurnal Psikologi, (1), $37-47$.
Kumboyono. (2011). Analisis Faktor Penghambat Motivasi Berhenti Merokok Berdasarkan Health Belief Model Pada Mahasiswa Fakultas Teknik Universitas Brawijaya Malang. Jurnal Keperawatan Soedirman. Volume 6, No.1. Diakses 3 Desember 2015 dari http://download. portalgaruda.org/article.php? article $=10549 \&$ val $=715$.

Laksono Tri.(2008). Hubungan antara Dukungan Sosial dengan Intensi Berhenti Merokok pada Mahasiswa

Mar'at. (1984). Sikap Manusia. Perubahan serta Pengukurannya, Jakarta, Ghalia Indonesia.

Mafika, D.(2011). Pengaruh Pendidikan Sebaya (Peer Education) dari Istri pada Suami dtidai Dusun Kweden, Desa Trirenggo Bantul Terhadap Peningkatan Pengetahuan, Sikap, Perilaku Suami untuk tidak merokok di dalam Rumah. Karya tulis ilmiah.Yogyakarta: Program Studi Ilmu Keperawatan Fakultas Kedokteran dan Ilmu Kesehatan Universitas Muhammadiya Yogyakarta.

Musaeni, YN., Ichsan, B., Basuki, SW. (2011). Pengaruh pendidikan kesehatan terhadap pengetahuan dan sikap merokok pada siswa laki-laki kelas kelas IX SMK Murni 1 Surakarta. Jurnal Kesehatan, ISSN 1979-7621, vol.4 No.2.

Notoadmodjo. (2012). Metodologi Penelitian Kesehatan. Jakarta: Rineka Cipt

Nursalam. (2011). Konsep dan Penerapan Metodelogi Penelitian Ilmu Keperawatan (EdII). Jakarta. Salemba Medika

Nursalam. (2013). Metodologi Penelitian Ilmu Keperawatan. Jakarta: Salemba Medika.

Putra, Bimma (2013). Hubungan Antara Intensitas Perilaku Merokok dengan Tingkat Insomnia. Karya Tulis Ilmiah stara satu Universitas Negeri Semarang.

Putri. (2010). Hubungan Antara Tingkat Pengetahuan Tentang Rokok Terhadap Perilaku Merokok Pada Siswa Kelas II SMK Bhinneka Patebon Kendal. Kendal : STIKES Kendal.

Rahmadi, A., Lestari, Y., Yenita. (2013). Hubungan Pengetahuan Dan Sikap Terhadap Rokok Dengan Kebiasaan Merokok Siswa SMP Di Kota Padang. Jurnal Kesehatan Andalas.

Sari, N.I.(2011). Hubungan Antara Tingkat Stres dengan PerilakuMerokok pada Siswa Laki-Laki Perokok Smkn 


\section{NURSING \\ PRACTICES}

2 Batusangkar. Skripsi, strata satu. Universitas Andalas, Padang.

Sismanto. (2015). Persepsi Bahaya Merokok Bagi Kesehatan pada Mahasiswa Prodi Pgsd Fkip. Skripsi, strata. Universitas Muhammadiyah Surakarta,Surakarta.

Siswanta, K., Sudarsana, K., Sudipta, K. (2014). Analisa Sikap d an Perilaku Kobsumen Terhadap Pemilihan Rumah Tinggal pada Kawasan Sunset Garden di Kota Denpasar, Bali. Jurnal Spektran, 44-51. Diakses pada 17 Desember 2015, dari http://ojs.unud.ac.id/index.php/jsn/article/ view/7902/0.

Susilo, Suko. (2009). Psikologi Sosial.Surabaya: Jenggala Pustaka Utama

Tobacco Control Support Center. Fakta Tembakau Permasalahannya di Indonesia tahun 2010. Jakarta: TCSCIAKMI; 2014

Tulenan, M., Rompas, S., Ismanto, A.Y. (2015). Hubungan Perilaku Merokok dengan Prestasi Belajar pada Remaja Perokok di Sma Negeri 1 Remboken. ejournal Keperawatan (e-Kp), 3 (2).

Virly Monica.(2013). Hubungan Persepsi Tentang Bahaya Merokok dengan Perilaku Merokok pada Karyawan di PT Sintas Kurama Perdana Kawasan Industri Pupuk Kujang Cikampek. Skripsi, strata satu. UIN Syarif Hidayatullah, Jakarta.

World Health Organization. (2011). WHO report on the global tobacco epidemic warning about the dangers of tobacco. Geneva 27 Switzerland.

Yusnia Ita. (2015). Meningkatkan Sikap Tidak Merokok Melalui Layanan Bimbingan Kelompok Dengan Model PBL. Penelitian Tindakan Bimbingan dan Konseling, 1, No. 2, Mei 2015. 